\title{
Determining Factors for Delisting of Companies Listed on BM\&FBOVESPA ${ }^{*}$
}

\author{
Patricia Maria Bortolon \\ Universidade Federal do Espírito Santo, Centro de Ciências Jurídicas e Econômicas, Departamento de Ciências Contábeis, Vitória, ES, Brazil
}

Annor da Silva Junior

Universidade Federal do Espírito Santo; Centro de Ciências Jurídicas e Econômicas, Departamento de Ciências Contábeis, Vitória, ES, Brazil

Received on 07.23.2014 - Desk acceptance on 07.30.2014 - 2n version approved on 01.27.2015.

\begin{abstract}
Traditionally, the capital market has attracted the interest of scholars and researchers, motivated to understand the process of going public and trading securities of companies on a stock exchange. In this research context, an aspect had been neglected, something which indicates a gap in the body of knowledge about the capital market and corporate governance: delisting of companies. We aim to identify the determining factors for delisting companies from the Commodity \& Futures Exchange BOVESPA (BM\&FBOVESPA). Methodologically, this research has related a set of variables collected from secondary data available on the database of the Securities Commission of Brazil (CVM), BM\&FBOVESPA, and Economatica. By analyzing 227 listing cancellations, between 2001 and 2012, the results indicate that delisting of companies from BM\&FBOVESPA is determined by the following factors: (i) greater concentration of ownership and control; (ii) lower free float; (iii) lower liquidity of shares; (iv) greater availability of cash; and (v) larger size. The fact that the controlling shareholder is a public or private company determines significant differences in the decision to delist. While in the first case cash availability is the most important factor, in the second liquidity is the main determining factor for delisting. From the academic viewpoint, this research extends the studies on delisting, still incipient in the Brazilian capital market context. For the capital market, identifying the characteristics of companies prone to cancel listing may prevent investors concerned about inherent risks at the time of acquiring shares by the controlling group interested in delisting.
\end{abstract}

Keywords: corporate governance, public companies, delisting. 


\section{INTRODUCTION}

This article discusses aspects related to corporate governance (Blair, 1995; Hart, 1995) and, more specifically, to the process of delisting public companies whose shares were traded on stock exchanges (Miller \& Frankenthaler, 2003; Weir, Laing, \& Wright, 2005; Khan, Vilanova, \& Hassairi, 2011), focusing on the identification of determining factors for going private.

Analyzing the historical process of American capitalism, we observe the consolidation of the Modern Share Company (Berle \& Means, 1984), as a milestone in the evolution of the life cycle of an organization, when it was believed that the summit might be to become a public company, with shares traded in the financial market (Pagano, Panetta, \& Zingales, 1998; Burghof \& Schilling, 2003). In this sense, access to the financial market by making the company's shares available for trade in a stock exchange via initial public offering (IPO) was interpreted as an important stage in the development and maturation of companies.

However, in recent years, it has been observed in the financial market an opposite movement - delisting of public companies. As noticed by Michelsen and Klein (2011), in a research on going private in Germany, the number of companies that choose to delist has increased. Such findings contradict the linear interpretation on the life cycle of organizations, pointed out by Burghof and Schilling (2003).

According to Boot, Gopalan and Thakor (2006, 2008), the number of companies delisted in the United States of America (USA) grew in the late 1990s and early 2000s. In 1999, the indicators shown by the authors point out that 83 companies went private; in 2000 they were 86; in 2003, 262; and in 2004, 188 companies. According to the authors, the main reason for this was the drop in stock prices that occurred since 2000.

In a managerial approach, William M. Sinnet (2002), responsible for the report titled "Why private companies stay private", published by the Financial Executives International (FEI), found out that the executives interviewed listed the following advantages in delisting: (i) greater managerial autonomy granted to managers; and (ii) possibility to keep focused on long-term growth, rather than appreciating the short-term action, and quarterly results, among others. Executives also list some limitations of delisting in terms of: (i) shareholder's liquidity status in case of need to sell shares; (ii) access to sources of financing, since it is usual that lenders require personal guarantees from shareholders; and (iii) immediate assessment of the enterprise, as the company's shares are not usually traded, among others.

In the Brazilian financial market context, we observe the presence of two phenomena: going public and going private. Figure 1 illustrates the movement of capitalization of financial resources derived from the capital opening and closing moves of Brazilian companies listed on the Commodity \& Futures Exchange BOVESPA (BM\&FBOVESPA).

Data, made available by the World Federation of Exchanges (2014), indicate that the capitalization of resources derived from going public increased in 2007 and, afterwards, went through a period of oscillation and, then, decreased the amount of capitalized financial resources. Regarding the capitalization of resources coming from delisting, there was an increase in the amount of capitalized resources since 2007 and maintenance of this level in the subsequent years, until 2012. Data also reveal that there is a reverse move in the processes of going public and going private.

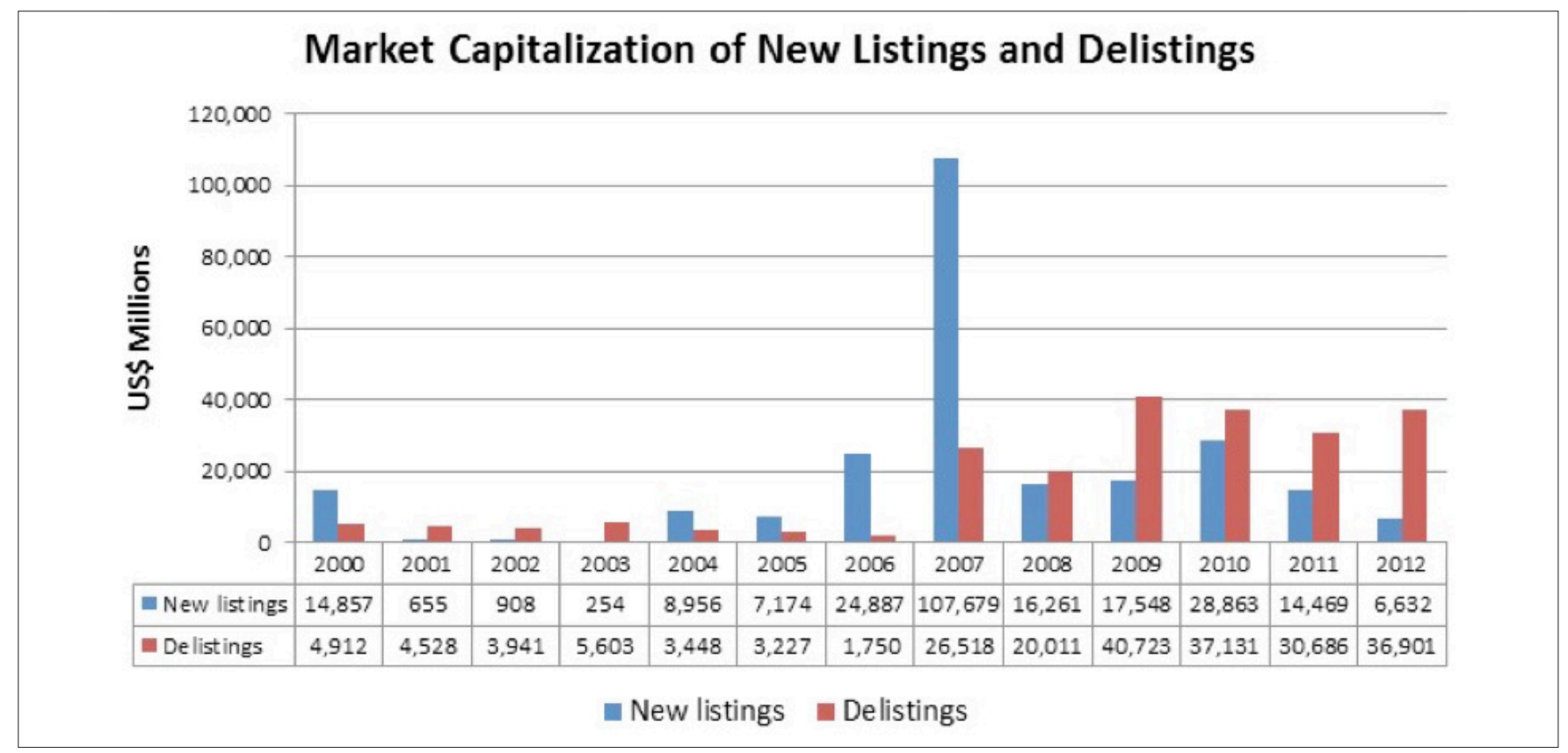

Source: World Federation of Exchanges (2014). 
Based on such evidence, it is understood that there is a need for investigating and thinking through the determining factors that lead public companies, which were believed to have, by going public, reached the highest stage of the life cycle (Burghof \& Schilling, 2003), to make the decision of submitting a public takeover offer for going private.

In part, the option to investigate the capital closing move is grounded and motivated by the following aspects: (i) increased costs of company's maintenance on the market, due to legal requirements that seek to minimize the possibility of corporate scandals, such as those in the cases of WorldCom and Enron; (ii) the theoretical and empirical evidence relating the financial system development to greater economic development (De Carvalho, 2002), making it relevant to investigate the delisting of companies from a market supposedly relevant to finance their growth; and (iii) the fact pointed out by Nóbrega, Loyola, Guedes Filho and Pasqual (2000) that going private is seen as a matter of concern, as it reduces the supply of shares, the number of business transactions, and market liquidity. Thus, according to the authors, the shrinkage in primary market and, consequently, the secondary market can stimulate foreign investment funds, for instance, to leave the Brazilian market. So, the market becomes less attractive for new companies, something which generates a bad vicious circle for developing the Brazilian financial market.

Having the theoretical arguments and empirical findings presented herein as a basis, we formulated the following research problem: "Which are the determining factors for delisting of Brazilian companies from BM\&FBOVESPA?" We defined as the general objective of research identifying and analyzing the determining factors for delisting of Brazilian companies from BM\&FBOVESPA. The study was conducted by collecting and analyzing secondary data, as it will be explained later in the topic that introduces the research methodology.

The article was structured into four topics, besides this introduction: (i) in the second topic we present the discussion on the delisting process and identify the determining factors for going private, discussed in the national and international literature and used in this survey; (ii) in the third, we approach the methodological aspects that indicate the procedures for data collection and analysis; (iii) in the fourth, we present, discuss, and analyze the survey results; and (iv) in the fifth and final topic, we draw our conclusions.

\section{DELISTING IN THE FINANCIAL MARKET: CLOSING THE CAPITAL OF LISTED COMPANIES IN DEBATE}

Although in the context of discussions on corporate governance and the financial market there is a predominance of studies addressing public companies, it can already be noticed in the international and national literature a set of studies on companies that made delisting, i.e. went private.

In the international literature, authors such as Olper and Titman (1993), Weir et al. (2005), and Khan et al. (2011) have observed, in the USA and England, a significant increase in the number and values of business transactions from public to private - in English, public-to-private (PTP) transactions -, where public companies leave the stock exchange, by means of delisting.

In this context of increased delisting move, Michelsen and Klein (2011) argue that the decision of going private cannot be just a result of ill-considered administration decisions or malfunction of the capital markets. There is also a need to consider the corporate life cycle, since corporate financing decisions involve a dynamic context (Burghof \& Schilling, 2003). When considering the life cycle, Michelsen and Klein (2011) argue that the variable company size plays a significant role in deciding for going private. According to the authors, small and mid-sized companies are more likely to experience undervaluation of their assets when compared to large corporations, and they are more prone to delisting. In part, this aspect is justified by the fact that small and mid-sized companies produce information less visible and less interesting to market agents, thus increasing the information asymmetry that determines company's undervaluation, and, as a consequence, attractiveness of delisting. On the other hand, company's growth is subject to the costs of providing required information to the capital market that tend to decrease as the company grows (DeAngelo, DeAngelo, \& Rice, 1984).

According to Miller and Frankenthaler (2003), in the American context, for instance, economic instability in the capital markets and the strict requirements imposed by the Sarbanes-Oxley Act (SOX), enacted in 2002, forced listed companies to assess the ratio between cost and benefit of keep trading their shares on the financial market. The cost of maintaining the public company's listing has become a key aspect, since the legal and accounting fees and other expenses related to record maintenance increased dramatically. In this sense, it is regarded as relevant that the public company assesses, on the one hand, the costs inherent to the legal and institutional requirements and, on the other, the advantages of this condition, such as better access to capital for business expansion, financing of operation diversification, enhanced corporate image within the financial market, and availability of a wide range of incentives for administrators and employees.

A relevant aspect regarding the decision for delisting, which seems to be a consensus in the literature, refers to the fact that capital markets showing a poor perfor- 
mance represent a relevant factor for going private. It is usual, in this type of market, to observe the presence of listed companies whose value is underestimated, as well as agency problems, which are acquired by other companies and delisted from the stock market to go through a restructuring process of the corporate governance model, becoming more efficient and effective and, as a consequence, more valuable than when they were listed in the stock market. These PTP transactions are characterized by the replacement of public by private monitoring, based on the concentration of ownership and operation of financial investors (Weir et al., 2005).

In the Brazilian literature, we observe few studies addressing this issue. Nevertheless, it is possible to find some studies that discuss, even peripherally, delisting, such as, for instance, Moreira (2000), who found out the impact of the stock repurchase announcement on price in the secondary market, investigating the existence of a positive or negative effect on shareholders' wealth; de Souza Costa, Almeida and Bortolon (2013) analyzed the effects of going private on earnings management in Brazilian companies. In turn, Eid Junior and Horng (2005) explored in a preliminary way the motivations that lead companies to go private.

In this study, Eid Junior and Horng (2005) investigated a number of companies that delisted from BM\&FBOVESPA between January 2000 and March 2005. Out of the total of 188 delisted companies, 50 were as a result of the incorporation of the company issuing the public takeover offer by another company listed on BOVESPA; 18 for lack of record update; 8 due to migration to another stock exchange; 103 for a voluntary request of the company; and 10 for various reasons that included liquidation and bankruptcy.

The main research findings were: (i) voluntary decision for listing cancellation derives from the analysis of costs and benefits of keeping as a listed company; (ii) when the costs to keep as a listed company are higher, the company decides for listing cancellation, seeking to increase the benefits as a private company; (iii) the variables company growth, free float, and liquidity in the trading of the shares are inversely proportional to the decision for going private, i.e. the greater these three variables, the lower the voluntary listing cancellation possibilities; and (iv) the variables company's size, big investors (proxy of monitoring costs), and costs to keep listed on BOVESPA were not significant regarding voluntary decision for listing cancellation (Eid Junior \& Horng, 2005).

It was based on studies and surveys carried out in the international and national context that we defined the set of determining factors for delisting companies (and the respective variables) that guided the process of data collection and analysis in this research, as shown in the subtopic below.

2.1 Set of Determining Factors for Going Private

To guide the empirical research, we defined eight determining factors for going private, and each of these factors will be measured with reference to a set of variables, namely: ownership structure (concentration of votes and free float), liquidity, cash availability, payment of dividends, growth, size, and indebtedness.

The first two factors are regarded as sub-factors related to the factor ownership structure. According to Lawrence (1986), Zillmer (2002), and Michelsen and Klein (2011), there is evidence that concentration of ownership characterized by concentration of votes is a crucial condition for conducting PTP transactions. Zillmer (2002) and Michelsen and Klein (2011) point out that in Germany, it is observed that a condition to going private is the fact that the biggest controller has $75 \%$ of the voting capital in the company. In part, this aspect is grounded because: (i) higher concentration reduces the cost of coordinating the delisting process; and (ii) the higher control concentration, the easier the process to approve the delisting operation in the company's board of directors (Lawrence, 1986; Michelsen \& Klein, 2011).

Regarding free float, it is observed that the higher the proportion of shares on the hands of small investors (with a stake under 5\%), the more difficult the approving process in the general meeting will be. Thus, it is observed that companies with low free float are more prone to delisting (Eid Junior \& Horng, 2005; Michelsen \& Klein, 2011), since there is a decrease in the costs involved in the acquisition of shares circulating on the market that enable delisting (Zillmer, 2002).

The third factor is liquidity. Eid Junior and Horng (2005), Weir et al. (2005), and Michelsen and Klein (2011) argue that the lower the liquidity of shares, the greater the incentive to delisting, since the stock market loses its function as the element to assess the company and to enable the opportunity to diversify shareholders' risk. In this case, the low liquidity of shares hinders the company's capitalization process, favoring company delisting from the stock exchange.

Cash availability is pointed out as the fourth factor. In line with the previous argument and also with the wish for greater discretion over the group's cash by managers/controllers, we expect a positive ratio between cash availability and probability to go private (Jensen, 1986; Weir et al., 2005). According to Jensen (1986), in public companies managers have incentives to retain cash, because there is greater discretion over this, something which represents an agency conflict. Going private reduces this cost, since it represents an increased stake of managers/controllers on the company. In addition, a decrease in this cost can occur when going private is financed by the capital of third parties that monitor application in the company's shares. The aspect free cash flow is, according to Jensen (1986), linked to growth opportunities. The author claims that firms with high free cash flow, but having low growth opportunities may invest the resources in a set of dubious corporate projects in terms of present value, due to the limited opportunities for profitable investments in the company's operating area.

Payment of dividends is the fifth factor. According to Jensen (1986), Weir et al. (2005), and Michelsen and Klein 
(2011) mature companies with low need for investments, especially in research and development (R\&D), can go through high payment of dividends. Thus, payouts may be subject to conflicts of interest between shareholders and managers, since the latter want to manage the resource distributed as dividends otherwise. However, in the literature on ownership structure there is evidence of using dividends as a way of signaling to minority shareholders that they will not be expropriated. Jordan, Liu and $\mathrm{Wu}$ (2014) show that firms having two classes of shares (with or without voting rights) pay more dividends than those having only shares with voting rights. Masulis, Pham and Zein (2011) observe business groups in 45 countries and they have observed higher payment of dividends in family groups. Bortolon (2013) found out higher payment of dividends in pyramidal control structures in Brazil.

The sixth factor is growth. The capital market is attractive for companies with high demands for investment, something which is not a characteristic of cash-generating and mature companies. Thus, authors advocate for the existence of an inversely proportional ratio between growth and the decision for delisting (Eid Junior \& Horng, 2005; Boot et al., 2008; Michelsen \& Klein, 2011; Khan, Vilanova \& Hassairi, 2011).

Size is the seventh factor. The smaller the company, the smaller the amount of information generated and disclosed to the market; the lesser attention given to it by the market; less analysts follow it up and this will tend to affect the liquidity of its shares and the company's assessment. Thus, it is expected that the smaller the company, the greater the probability of delisting (Boot et al., 2008; Michelsen \& Klein, 2011).

The eighth and final factor is indebtedness. Companies with lower indebtedness are more likely to go private, due to the potential financing through debt and the expected value of the tax benefits if the company is profitable (Michelsen \& Klein, 2011).

In order to operationalize the analysis of determining factors for going private, variables related to each of the factors were defined (Table 1).

Table 1 Operational definition of the variables analyzed in the survey

\begin{tabular}{|c|c|c|}
\hline \multicolumn{3}{|c|}{ Definition of variables } \\
\hline Variable(s) & Description / measurement & $\begin{array}{l}\text { Expected } \\
\text { sign }\end{array}$ \\
\hline \multicolumn{3}{|l|}{ Factor 1: Ownership structure } \\
\hline $\begin{array}{l}\text { Stake of the biggest shareholder in } \\
\text { shares entitled to vote. }\end{array}$ & Average percentage of shares entitled to vote of the biggest shareholder. & \\
\hline $\begin{array}{l}\text { Stake of the biggest shareholder in the } \\
\text { total shares. }\end{array}$ & Average percentage of total shares of the biggest shareholder. & + \\
\hline $\begin{array}{l}\text { Biggest shareholder's deviation of } \\
\text { rights. }\end{array}$ & $\begin{array}{l}\text { Ratio between the equity stake in shares entitled to vote and the total shares of the biggest sha- } \\
\text { reholder. Obs.: in each of the three years prior to cancellation and calculating the mean value. }\end{array}$ & \\
\hline Free float of shares entitled to vote. & $\begin{array}{l}\text { Average percentage of shares entitled to vote held by "Other" shareholders (having under } 5 \% \text { of } \\
\text { capital). }\end{array}$ & \\
\hline Free float of total shares. & Average percentage of total shares held by "Other" shareholders (having under $5 \%$ of capital). & - \\
\hline \multicolumn{3}{|l|}{ Factor 2: Liquidity } \\
\hline Liquidity. & $\begin{array}{l}\text { Average liquidity in the most liquid stock. The observed liquidity is that calculated by Economatica } \\
\text { according to the equation Liquidity }=\frac{p}{p} \sqrt{\frac{n}{N} \times \frac{v}{v}} \text {, where, for a certain period } \mathrm{p} \text { is the number of days } \\
\text { over which there was negotiation with the share, } \mathrm{P} \text { is the total number of days with trading on the } \\
\text { market, } \mathrm{n} \text { is the number of transactions with the share, } \mathrm{N} \text { is the total number of transactions on the } \\
\text { market, } \mathrm{v} \text { is the volume traded with the share, and } \mathrm{V} \text { is the total volume traded on the market. }\end{array}$ & - \\
\hline Presence on the stock exchange. & Average percentage of days in the year over which the share was traded. & \\
\hline \multicolumn{3}{|l|}{ Factor 3: Cash availability } \\
\hline Ebitda & Average Ebitda. & \\
\hline Ebitda / revenue & Average ratio Ebitda / revenue. & $T$ \\
\hline \multicolumn{3}{|l|}{ Factor 4: Payment of dividends } \\
\hline Dividend yield & Average ratio between paid dividend and share value. & - \\
\hline \multicolumn{3}{|l|}{ Factor 5: Growth } \\
\hline Revenue growth. & Average of the two revenue growth percentages. & \\
\hline Fixed asset growth. & Average of the two fixed asset growth percentages. & \\
\hline Market value growth. & Average of the two market value growth percentages. & - \\
\hline Market value / equity. & Average of the ratio market value / equity. & \\
\hline \multicolumn{3}{|l|}{ Factor 6: Size } \\
\hline $\operatorname{Ln}$ of revenue. & Average of the logarithm of revenue. & \\
\hline Ln of market value. & Average of the logarithm of market value. & - \\
\hline
\end{tabular}

Factor 7: Leverage 
All variables were observed in the three years previous to delisting, both for companies that went private and those defined as "comparable". The average values of the three years previous to listing cancellation were observed, in order to reduce the influence of momentary variations, thus capturing values that better reflect the analysis factor concerned. Control group companies also had their averages observed within the same periods of a similar (comparable) that went private. Failure to include the cancellation year when calculating the averages is justified by the fact that many companies no longer send the Securities Commission of Brazil (CVM) data on financial statements for the cancellation year.

\section{METHODOLOGICAL ASPECTS}

Methodologically, this research is characterized as a quantitative study with a descriptive and analytical nature (Tripodi, Fellin, \& Meyer, 1981) by collecting secondary data from the database of the CVM, BM\&FBOVESPA, and Economatica. We defined as study population the set of all companies listed on BM\&FBOVESPA that voluntarily went private through listing cancellation request to the CVM, within the 12-year period between 2001 and 2012. As pointed out by Eid Junior and Horng (2005), not voluntary cancellations mainly occur due to deterioration of the company's outcomes. Companies' noncompliance with the regulating agency for a long period is also usual in these cases, making it difficult to obtain reports for analysis.

\subsection{Database}

Within the period under investigation, 256 cancellation records were observed. We excluded from the study 27 "cancellations by letter" and 2 cancellations by "elision through company's extinction", because they are involuntary, leaving a set of 227 cancellations to analyze, thus constituting the survey sample.

In order to operationalize data analysis, we chose the definition of a control sampling group, named as "comparable", consisting of companies in the same industry and having the same size of companies that delisted, but they remained listed. We adopted the 20 industries used in the classification by the database of Economatica. By means of a list sorted by industry and size of assets, we sought the canceled company and that remaining active which was closer to it in the list mentioned. This procedure enabled us to identify a total of 150 "comparable" companies to make up the control group.

The database of companies that delisted was analyzed according to two starting points: the legal status of main shareholder (controller) who determined delisting and the motivations for going private.

\subsection{Legal Status of the Main Shareholder}

The legal status of the main controlling shareholder who determined delisting is a crucial variable in the analysis of the phenomenon delisting. Companies that canceled registration may have been incorporated or have public companies as controllers. In such situations, somehow, even indirectly, its outcomes might be known and addressed by market analysis. So, we conducted an analysis on the ownership structure of the 227 companies in the cancellation year, observing the shareholders' stake disclosed in annual information (ANI) (until 2008) and the reference form (REF) (from 2009). In 26 companies it was not possible to identify the ownership structure, leaving 201 companies for analysis. The results are displayed in Table 2.

Table 2 Legal status of the main shareholder who determined delisting

\begin{tabular}{lcc}
\hline & Main shareholder & \\
\hline Type of shareholder & Quantity & Frequency \\
\hline Controller (closely held corporation) delisted & 50 & $24.9 \%$ \\
Controller (public company) delisted & 49 & $24.4 \%$ \\
Controller (Limited Liability Company - LLC) delisted & 29 & $14.4 \%$ \\
Foreign controller delisted & 29 & $14.4 \%$ \\
Incorporated by public company & 22 & $10.9 \%$ \\
Natural person as controller delisted & 9 & $4.5 \%$ \\
Controller (government) delisted & 3 & $1.5 \%$ \\
Controllers (LLC, and natural persons) & 3 & $1.5 \%$ \\
Controller (investment fund) delisted & 2 & $1.0 \%$ \\
Foreign funds delisted & 2 & $1.0 \%$ \\
Controller (holding company) delisted & 1 & $0.5 \%$ \\
Controller (pension funds and other) delisted & 1 & $0.5 \%$ \\
Controller (joint-capital company) delisted & 1 & $0.5 \%$ \\
\hline Overall total & $\mathbf{2 0 1}$ & $\mathbf{1 0 0 . 0} \%$ \\
\hline
\end{tabular}


Based on these results, it is observed that around 44\% of companies may be regarded as delisted companies in fact, because controllers are closely held corporations (50), LLC (29), or natural persons (9). However, about $35 \%$ will have some visibility to the market, since controllers are public companies (49) or they were incorporated by public companies (22). It is also worth stressing the percentage of $14.4 \%$ of companies controlled by foreigners who decided to delist. These data suggest the need for investigating possible differences in the determinants of the decision to go private due to the characteristics of the main controllers.

\subsection{Motivations for Going Private}

The investigation on the motivation for going private was conducted by means of the public documents disclosed by companies themselves and made available on the website of the CVM. Table 3 displays a synthesis of the most common reasons reported by the companies themselves to relate the status of the main controller with higher frequency. The count does not total 227 companies, since several reasons may be listed by the same company. It was possible to survey the documentation of 221 out of the 227 companies, among these, 137 listed the reasons. Therefore, Table 3 displays the frequency of motifs observed in 137 of these companies.

Table 3 Motivations reported by companies to for listing cancellation and controller status

\begin{tabular}{l|l|l}
\hline Reason Mentioned & Freq. & Controlling Shareholder Status \\
\hline Corporate reorganization & 62 & $\begin{array}{l}\text { Controlling shareholder public company (37) } \\
\text { Controlling shareholder closely held corporation (8) }\end{array}$ \\
\hline Cost-cutting & 37 & $\begin{array}{l}\text { Controlling shareholder public company (13) } \\
\text { Controlling shareholder LLC (8) }\end{array}$ \\
\hline Instrução CVM No 361/358/480/287 & 31 & $\begin{array}{l}\text { Controlling shareholder closely held corporations (14) } \\
\text { Foreign controlling shareholder (7) }\end{array}$ \\
\hline Greater control & & Incorporated by public company (4) \\
\hline Stronger position in the market & 11 & Controlling shareholder (public company) delisted (5) \\
\hline Unification of brands & 9 & Controlling shareholder (public company) delisted (3) \\
\hline Unattractive shares on the market & 7 & Controlling shareholder LLC delisted (4) \\
\hline Privatization & 5 & Controlling shareholder (government) delisted (3) \\
\hline Increased equity & 4 & Controlling shareholder (public company) delisted (2) \\
\hline No interest in investing in Brazil & 3 & Controlling shareholder LLC delisted (1) \\
\hline Lack of updating & 1 & Controlling shareholder (closely held corporation) delisted (1) \\
\hline TOTAL & 1 & \\
\hline
\end{tabular}

Source: Prepared by the authors.

As it can be seen, the main reasons are corporate reorganization and cost-cutting. In part, such results may be regarded as interdependent and aligned with the international literature. As Miller and Frankenthaler (2003) emphasize, there is a need that the public company assesses the ratio between the cost and the benefit of keeping up as publicly traded or choose to go private.

In a way, cost-cutting is related, in various forms, to the company's corporate reorganization. As a rule, this reorganization is, among other factors, linked to the search for performance gain arising from the need to implement a restructuring process of the corporate governance model, which involves replacement of public monitoring by the private one and the concentration of ownership through the acquisition of shares available on the market, via the capital closing move (Weir et al., 2005).

When trying to observe the intersection of reported motivations with the nature of the main shareholder, data doesn't show predominance of one type of motivation for a particular type of controller, and the most cited reasons emerging from the documents published by companies controlled both by public and private companies.

\subsection{Econometric Models}

To analyze the determining factors of the decision for delisting, logit models were used with the following conceptual framework:

$\left.\operatorname{Prob}_{\text {Delisting }_{i}}=1\right)=\alpha_{i}+\beta_{1}$ OwnershipStructure $_{i}+$

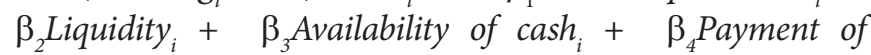
dividends $_{i}+\beta 5$ Growth $_{i}+\beta 6$ Size $_{i}+\beta$ BLeverage $_{i}$

The variable "Delisting" has a binary nature, which takes the value 1 if the company canceled listing and 0 otherwise. The way how the model's factors were operated was described in Table 1.

\section{PRESENTATION, DISCUSSION, AND ANALYSIS OF RESULTS}

This topic presents the results of statistical analysis conducted with the secondary data of the two groups under investigation: (i) from delisted companies; and (ii) from "comparable" companies, belonging to the con- 
trol group, which remained public. This topic is structured into two parts: the first presents the descriptive statistics and average comparison tests and the second part presents the multivariate analyses (general and segmented by the controlling shareholder's status).

\subsection{Descriptive Statistics and Average Difference Tests}

The economic and financial variables used to measure the determining factors for delisting, highlighted in Table 1, were obtained from the database of Economatica. Out of the 227 companies, it was possible to obtain data on at most 165 companies. For some variables, this number dropped to less than half. This fact is justified by the availability of data in Economatica, constituting a limitation of this survey. Regarding the control group, it was possible to identify 150 similar companies, however, publicly traded ("comparable"), to perform a comparative analysis with the 165 delisted companies. Also for this control group, data concerning some variables were not available. The presentation of results has been subdivided into two parts: (i) one concerning the analysis of the determining factors in general, whose descriptive statistics and the results of average comparison tests are displayed in Table 4; and (ii) another with the same nature, however, segmented by two types of controllers, namely, public and private companies, whose results are displayed in Table 5.

Among the results displayed in Table 4 it is worth highlighting that, regarding the factor ownership structure, the variables control concentration (74.79\%) and ownership concentration (54.59\%) observed in the group of companies that went private were higher when compared to companies that remained with listed $(60.27 \%$ and $44.61 \%)$ and they were statistically significant at $1 \%$. Free float is also significantly lower, both in the total shares and in the shares entitled to vote. In addition, free float data suggest that the liquidity of shares of delisted companies is lower than that of those remaining publicly traded, however, no statistical significance was found for the differences observed in liquidity proxies. These results corroborate the empirical evidence found by Eid Junior and Horng (2005).

Despite the criticism against using Ebitda as a proxy for operating cash flow (Marçal, 2006; Salotti \& Yamamoto, 2005), the mandatory cash flow statement only from 2008 on and the absence of this information in part of the period under analysis motivated its adoption as a measure of cash availability. The difference is statistically significant for the ratio Ebitda / revenue, something which suggests greater discretion on the part of the main shareholders and this is in line with the papers by Jensen (1986) and Weir et al. (2005). This rationale, however, is not repeated in the analysis of dividend yield. The average value of this variable is lower in the group that went private, but the difference is not statistically significant. It was also not possible to observe differences in the indebtedness levels of the two groups.

Low growth as motivation for delisting has not been confirmed by any of the 4 proxies employed in the research, although 3 of them have lower averages for the delisted group, the differences are not statistically significant. These results go against those reported by Eid Junior and Horng (2005), although it is worth pointing out that the authors do not work with similar companies and they adopt various time frames for listed and delisted companies. The differences in size between companies are strongly significant, and those that delisted are larger than those that remain listed. This finding may both signal that those delisted are more mature or have lower growth opportunities.

As a robustness test, differences were observed in the averages of the 2 previous years and the year before. No significant differences were observed in the findings from the average of the 3 years preceding the listing cancellation. The table reports only the statistics of the $t$-tests performed, due to space constraints.

In turn, regarding Table 5, it is observed that the characteristics of ownership and control concentration are quite homogeneous between the two types of controllers, however, the proxies of liquidity that in Table 4 showed no significant differences show, here, a clearly lower liquidity for those having as controller at the listing cancellation time a privately held company. The results are the same for the averages of the 2 previous years and the year before. Cash availability in companies that, at the delisting time, had public companies as controllers were larger than those with a privately held controller. This finding seems to signal that delisting may be important to provide more discretion to use this cash within the controlling business groups (Jensen, 1986). Again, the conclusions are repeated with regard to averages at various times. 
Table $4 \quad$ Descriptive statistics and t-tests of average differences for independent samples

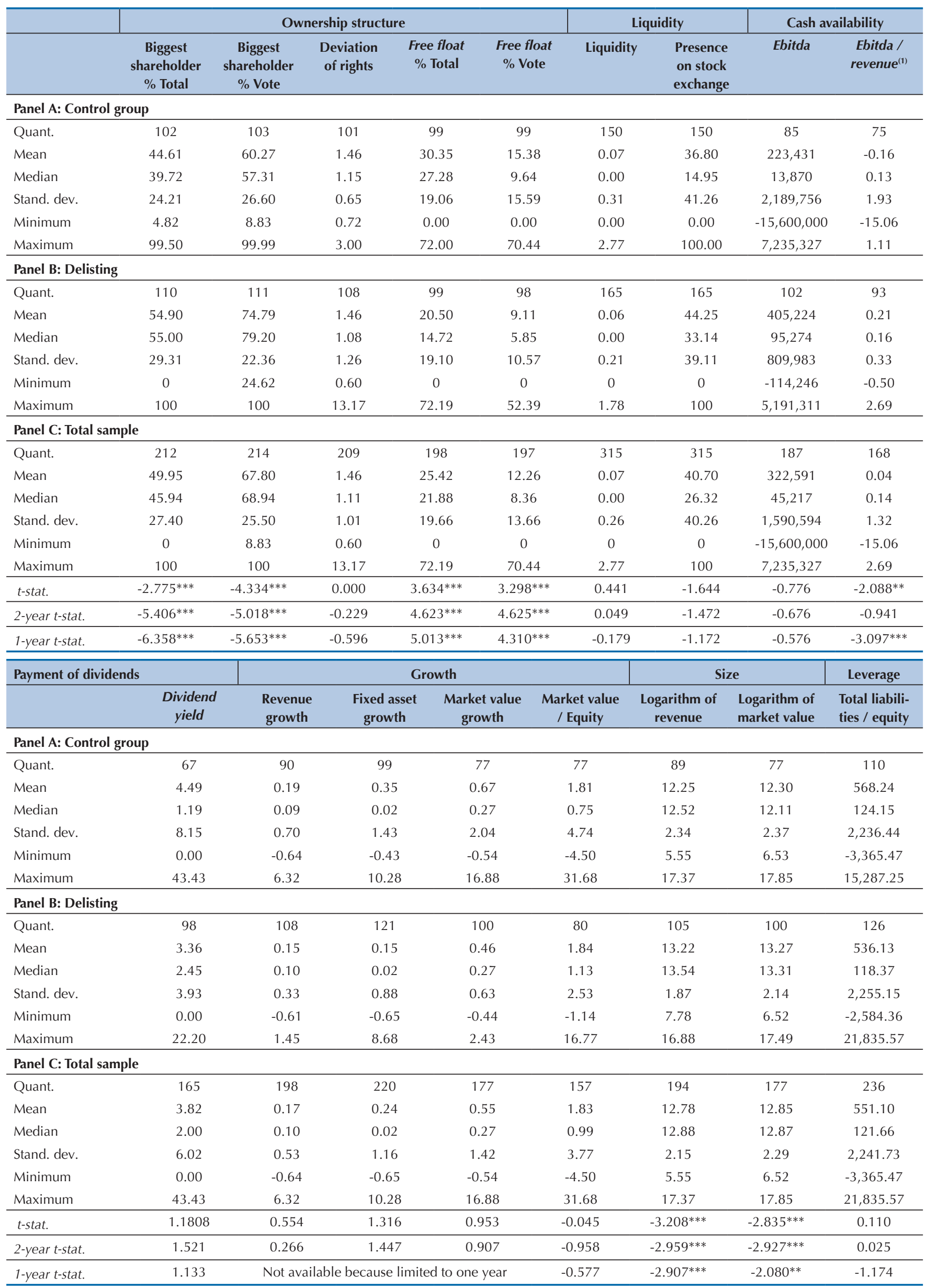

(1) Variable Winsorized at $2.5 \%$ in each end of the distribution to mitigate the problem of outliers.

Note: All variables are averages of the three years preceding listing cancellation, including the control group companies. Asterisks indicate statistical significance at $1 \%$ $\left({ }^{* *}\right), 5 \%\left({ }^{* *}\right)$, and $10 \%(*)$.

Source: Prepared by the authors. 


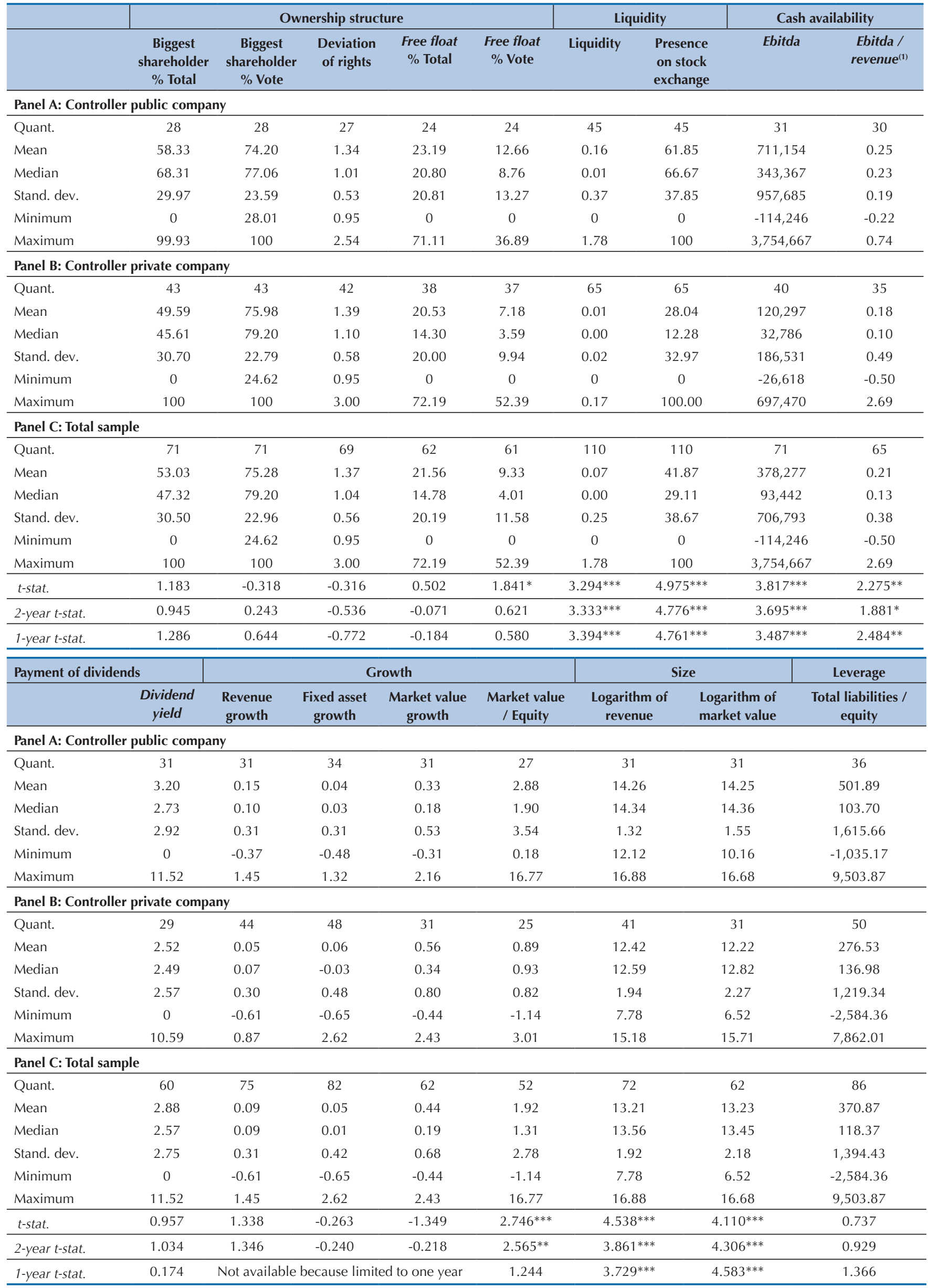

(1) Variable Winsorized at $2.5 \%$ in each end of the distribution to mitigate the problem of outliers.

Note: All variables are averages of the three years preceding listing cancellation. Asterisks indicate statistical significance at $1 \%\left({ }^{* * *}\right), 5 \%\left({ }^{* *}\right)$, and $10 \%(*)$.

Source: Prepared by the authors. 
Growth opportunities seem to be greater for the group whose controller was listed when observing the ratio market value/equity. As the number of observations is small regarding this variable, non-parametric methods were used (Wilcoxon and Kruskal-Wallis tests) and they showed results consistent with the previous ones. The results remain for the averages of the two previous years and the year before.

The group of companies whose controller was listed is also larger than the group with privately held controller. Such finding is repeated for the averages of the two previous years and the year before.

\subsection{Multivariate Analyses}

The multivariate analysis, displayed in Table 6, highlighted findings consistent with those observed in the average difference tests. The variable with the most consistent and statistically significant results is the ratio Ebitdal revenue, indicating that companies with good capacity to generate operating cash flow are more likely to go private. This finding is consistent with the arguments by Jensen (1986) on the search for greater discretion in the use of resources generated in the business.

Liquidity is negatively related to the chances of going private, as expected. With lower liquidity, the stock market loses its function as element signalizing the business value, something which also increases the asymmetry of information and makes it difficult to raise new funding (Weir et al., 2005; Michelsen \& Klein, 2011).

The ownership structure is also a determining factor in the decision to go private, as pointed out by Lawrence (1986) and Michelsen and Klein (2011); this is identified by Eid Junior and Horng (2005) in Brazil, too. The greater the biggest shareholder's stake (voting capital or total capital), the greater the company's chances to go private. Free float has coefficients according to the expected signal indicating that the higher the free float, the lower the chance of delisting. However, although with significant differences in the univariate analysis, here, the results are not statistically significant. Eid Junior and Horng (2005) find a significant and negative relation, however, they do not use stakes as explanatory variables, something which may explain the difference in results.
Size, measured by the logarithm of revenue, has an opposite sign than expected and it indicates that the larger the company size, the greater the chance of going private. The results are divergent with regard to the arguments by Boot et al. (2008) and Michelsen and Klein (2011). According to the authors, smaller companies draw less attention from the market and analysts, something which might decrease liquidity and increase the chance of going private. The logarithm of revenue in this analysis, however, may reflect the greater business maturity and a reduced need for investments, something which might decrease the attractiveness of the capital market as a source of funding, thus explaining the positive relation to the chance of going private. Another possible explanation is related to the fact that larger companies have greater managerial complexity and they are more likely to agency conflicts due to the greater difficulty of monitoring the agent by the principal shareholder (Jensen \& Meckling, 1976).

As a robustness test, the models were estimated considering the averages of variables in the two years previous and the year before. The results are not essentially different, keeping the same signs. However, the statistical significance is stronger for the results of stake concentration and less strong for Ebitda/revenue and liquidity. The variables related to free float have a statistical significance at $5 \%$ in models with averages variables in the two previous years and $1 \%$ for the year before. The results are not shown due to space constraints.

The higher significance of variables related to ownership structure (percentage of the biggest shareholder and free float) in the analyses of the two previous years and the year before is coherent with the evolution observed between the third year and the year before listing cancellation. Average difference tests for these variables by comparing the values three years before to that one year before listing cancellation show statistically significant differences. Equity stakes, both in terms of votes and the total amount, become more concentrated and free float decreases, something which seems to signal a preparation move for listing cancellation. The results are available for reading with the authors.

\section{Table $6 \quad$ Logit models}

\begin{tabular}{|c|c|c|c|c|c|}
\hline Variables & $\begin{array}{c}(1) \\
\text { model } 1 \\
\end{array}$ & $\begin{array}{c}(2) \\
\text { model } 2 \\
\end{array}$ & $\begin{array}{c}(3) \\
\text { model } 3 \\
\end{array}$ & $\begin{array}{c}(4) \\
\text { model } 4\end{array}$ & $\begin{array}{c}(5) \\
\text { model } 5 \\
\end{array}$ \\
\hline Biggest shareholder & $0.0205^{*}$ & $0.0193 *$ & & & \\
\hline$\%$ vote & $(0.0104)$ & $(0.0108)$ & & & \\
\hline Biggest shareholder & & & $0.0242^{* *}$ & & \\
\hline$\%$ total & & & $(0.0122)$ & & \\
\hline Free float & & & & -0.0323 & \\
\hline$\%$ vote & & & & (0.0205) & \\
\hline Free float & & & & & -0.0227 \\
\hline$\%$ total & & & & & $(0.0162)$ \\
\hline \multirow[t]{2}{*}{ Liquidity } & $-1.959^{* *}$ & & $-2.070^{* *}$ & $-2.313^{* *}$ & $-1.632^{* *}$ \\
\hline & (0.994) & & $(0.959)$ & $(0.947)$ & $(0.830)$ \\
\hline
\end{tabular}

(cont.) 


\begin{tabular}{|c|c|c|c|c|c|}
\hline Presence on & & $-0.0242 * *$ & & & \\
\hline stock exchange & & $(0.0117)$ & & & \\
\hline \multirow[t]{2}{*}{ Ebitda / revenue } & $7.842^{* * *}$ & $6.825^{* * *}$ & $9.424^{* * *}$ & $9.865^{* * *}$ & $8.143^{* * *}$ \\
\hline & $(2.781)$ & $(2.486)$ & $(3.160)$ & $(3.176)$ & $(2.847)$ \\
\hline \multirow[t]{2}{*}{ Dividend yield } & -0.0651 & $-0.102 *$ & -0.0609 & -0.0454 & -0.0615 \\
\hline & $(0.0467)$ & $(0.0592)$ & $(0.0435)$ & $(0.0447)$ & $(0.0437)$ \\
\hline Market value / & -0.131 & -0.195 & -0.226 & -0.177 & -0.203 \\
\hline equity & $(0.140)$ & $(0.123)$ & $(0.148)$ & $(0.146)$ & $(0.133)$ \\
\hline Logarithm of & $0.505^{* *}$ & $0.595^{* * *}$ & $0.569^{* *}$ & $0.599^{* * *}$ & $0.424^{* *}$ \\
\hline revenue & $(0.202)$ & $(0.220)$ & $(0.223)$ & $(0.231)$ & $(0.209)$ \\
\hline Total liabilities / & 0.000491 & 0.000330 & 0.000819 & 0.000667 & 0.000747 \\
\hline equity & $(0.000807)$ & $(0.000820)$ & $(0.000870)$ & $(0.000994)$ & $(0.000765)$ \\
\hline Constant & $(2.970)$ & $(2.808)$ & $(3.126)$ & (3.169) & $(2.927)$ \\
\hline Observations & 87 & 87 & 85 & 80 & 82 \\
\hline chi2 & 31.27 & 30.59 & 35.38 & 30.31 & 26.00 \\
\hline $\mathrm{p}$ & $5.53 \mathrm{e}-05$ & $7.41 \mathrm{e}-05$ & $9.50 \mathrm{e}-06$ & $8.33 \mathrm{e}-05$ & 0.000504 \\
\hline r2_p & 0.261 & 0.256 & 0.303 & 0.274 & 0.230 \\
\hline
\end{tabular}

Note: Standard deviations in parentheses.

Note: Models with binary dependent variable that takes value 1 if the company delisted and 0 otherwise. Asterisks indicate statistical significance at $1 \%(* * *), 5 \%(* *)$, and $10 \%(*)$.

Source: Prepared by the authors.

Table 7 explores possible differences in determinants, taking into account the different types of controller. We adopted the model 1 from Table 7 as base specification and the dependent variable was moved, considering for calculation only companies with the specified characte- ristics (public or privately held controller). The choice of model 1 is justified by the possibility of assessing the biggest shareholder's stake in the voting capital, the most relevant variable in the analysis of differences by type of controller.

Table 7 Logit models segmented by type of controller

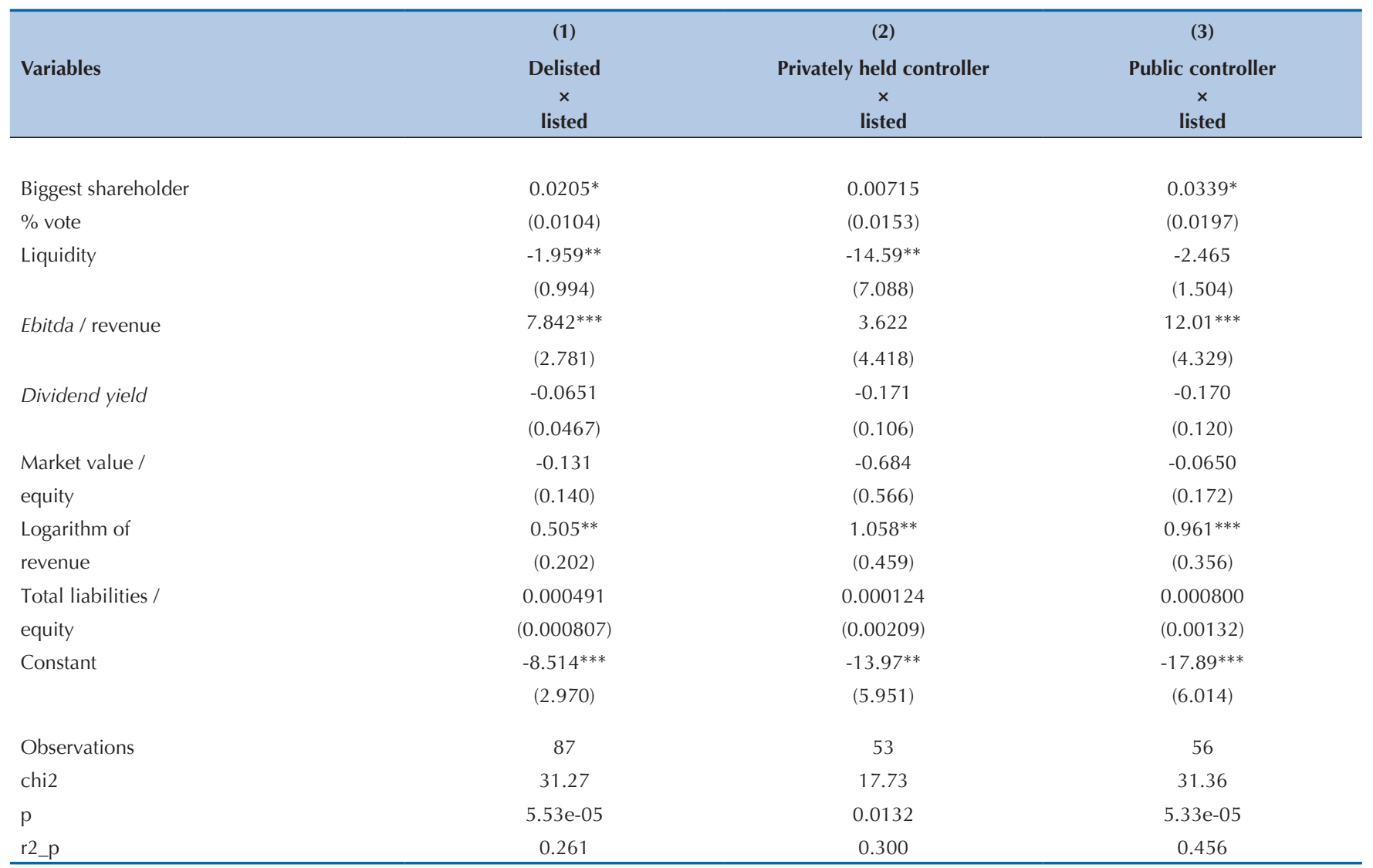

Note: Standard deviations in parentheses.

Note: Models with binary dependent variable that takes value 1 if the company delisted in model 1 , if it delisted having a privately held company as controller in model 2, if delisted having public company as controller in model 3; and 0 otherwise. Asterisks indicate statistical significance at $1 \%\left({ }^{* * *}\right), 5 \%(* *)$, and $10 \%(*)$. Source: Prepared by the authors. 
The results show that the determinants are different depending on whether there is a public or privately held controller at the time of listing cancellation. Liquidity, in negative relation to the chance of delisting, as expected (Weir et al., 2005; Michesen \& Klein, 2010), consistently significant in the previous analysis, is significant only in the model with companies having a privately held controller. The coefficient is also more relevant (-14.59), showing greater impact on the chance of undergoing listing cancellation when the controller is privately held.

Different from what was observed with liquidity, the proxy for cash availability, the variable Ebitda/revenue shows up as statistically significant only in the model with com- panies having a privately held controller. Greater discretion for operating cash generation seems to be more relevant to companies controlled by other ones publicly traded, possibly because there are more synergistic opportunities with other businesses of this privately held controller.

Concentration of voting power, marginally significant in the base model with all companies that went private, loses significance in the model with companies whose controllers were privately held. For the other variables there are not differences between the types of controller. Size, approximate by the logarithm of revenue, has a positive relation to the chance of delisting in all three models.

\section{CONCLUSIONS}

The results indicate that delisting of companies traded on BM\&FBOVESPA is determined by the following factors: (i) greater concentration of ownership and control; (ii) lower free float; (iii) lower liquidity of shares; (iv) greater availability of cash; and (v) larger size.

The characteristic of the main shareholder also determines differences in these factors. Cash availability is the most important factor in the decision for delisting when the main shareholders are public companies and liquidity is the most relevant factor for companies whose main shareholders are privately held.

In part, the results are converging with the characteristics of the Brazilian capital market and the companies operating in it. According to Leal, Silva, and Valadares (2002), the Brazilian companies traded on stock exchanges are characterized by: (i) high concentration of voting power; (ii) various big shareholders' stake in the voting capital and total capital; and (iii) controlling shareholders with stakes beyond the needed to keep control.

Thus, it may be inferred that the decision for delisting companies traded on BM\&FBOVESPA seems to have in ownership and control concentration its central axis and the other factors show up as supplementary. In other words, the decision for delisting has its origin in the company's control maintenance (highest percentage of shares entitled to vote and not entitled to vote) and, through this factor, the others are gradually deployed until completion of the delisting process.

We hope that the results presented herein provide a guide for further studies and surveys on the theme in the academy and in the capital market and serve as warning signs for investors, in order to assess the likelihood that public companies have to delist or not and assess the positive and negative risks of investing in companies with these characteristics.

The study showed limitations, the main of them is lack of available data on companies that went through the delisting process. This is an intrinsic characteristic of this type of company due to the fact it is more prone to not sharing information with the market after delisting. In addition to these aspects, we emphasize that the study is focused on the analysis of factors inherent to the company and environmental factors were not captured, such as the financial crisis of 2008 , which is believed to have influenced on the listing cancellation moves (positively or negatively). 


\section{References}

Berle, A. A., \& Means, G. C. (1984). A moderna sociedade anônima e a propriedade privada. São Paulo: Abril Cultural.

Blair, M. M. (1995). Ownership and control: rethinking corporate governance for the twenty-first century. Washington, DC: The Bookings Institutions.

Boot, A. W. A,, Gopalan, R., \& Thakor, A. V. (2006, abril). The entrepreneur's choice between private and public ownership. The Journal of Finance; 61(2), 803-836.

Boot, A. W. A., Gopalan, R., \& Thakor, A. V. (2008, agosto). Market liquidity, investor participation, and managerial autonomy: why do firms go private? The Journal of Finance, 63(4), 2013-2059.

Bortolon; P. M. (2013). Por que as empresas brasileiras adotam estruturas piramidais de controle. Base: Revista de Administração e Contabilidade da Unisinos, 10, 2-18.

Burghof, H. P., \& Schilling, D. (2003). Going private als corporate governance transaktion. Betr Forsch Prax, BFuP, 5, 117-136.

DeAngelo, H., DeAngelo, L., \& Rice, E. M. (1984). Going private: minority freezeouts and stockholder wealth. Journal of Law and Economics, 27, 367-401.

De Carvalho, A. G. (2002). Desenvolvimento financeiro e crescimento econômico. Revista Econômica do Nordeste, 33(4), 694-715.

Eid Junior, W., \& Horng, W. J. (2005). A saída: uma análise da delistagem na BOVESPA. Recuperado de http://www.williameid.com.br/pdf/ deslistagem_bovespa.pdf

Hart, O. (1995, maio). Corporate governance: some theory and implications. The Economic Journal, 105(430), 678-689.

Jensen, M. (1986, maio). Agency costs and free cash flow, corporate finance and take-overs. American Economics Review, 76(2), 323-329.

Jensen, M., \& Meckling, W. (1976, outubro). Theory of the firm: managerial behavior, agency costs and ownership structure. Journal of Financial Economics, 3(4), 305-360.

Jordan, B. D., Liu, M. H., \& Wu, Q. (2014). Corporate payout policy in dual-class firms. Journal of Corporate Finance, 26, 1-19. Recuperado de 10.1016/j.jcorpfin.2014.02.004

Khan, H. U. R., Vilanova, L., \& Hassairi, S. A. (2011, junho). Effects of private equity investment on the decisions of European companies to go private: an empirical study. International Journal of Management, 28(2), 493-508

Lawrence, E. C. (1986). A comparative analysis of public firms going private. Review of Business and Economic Research, 21(2), 1-17.

Leal, R. P. C., Silva, A. L. C., \& Valadares, S. M. (2002, janeiro). Estrutura de controle das companhias brasileiras de capital aberto. Revista de Administração Contemporânea, 6(1); 7-18

Marçal, R. (2006). Ebtida: qual o real valor dessa métrica. Relações com Investidores, 96, 6-10

Masulis, R. W, Pham, P. K., \& Zein, J. (2011). Family business groups around the world: financing advantages, control motivations, and organizational choices. Review of Financial Studies, 24(11), 3556-3600
Michelsen, M., \& Klein, C. (2011, março). “Privacy please!”: the public to private decision in Germany. Review of Managerial Science, 5(1) 49-85.

Miller, D. A., \& Frankenthaler, M. J. (2003, outubro). Securities registration: delisting/deregistration of securities under the Securities Exchange Act of 1934. Insights, 17(10), 7-12

Moreira, L. F. (2000). A recompra de ações na BOVESPA (Dissertação de Mestrado). Universidade Federal do Rio Grande do Sul, Porto Alegre.

Nóbrega, M., Loyola, G., Guedes Filho, E. M., \& Pasqual, D. (2000). O mercado de capitais: sua importância para o desenvolvimento e os entraves com que se defronta o Brasil (Estudos para o Desenvolvimento do Mercado de Capitais da BOVESPA). São Paulo: BMF\&Bovespa.

Olper, T., \& Titman, S. (1993). The determinants of leverage buyout activity: free cash flow vs. financial distress costs. Journal of Finance, 48, 1985-1999.

Pagano, M., Panetta, F., \& Zingales, L. (1998, fevereiro). Why do companiès go public? An empirical analysis. The Journal of Finance, 53(1), 27-64.

Salotti, B. M., \& Yamamoto, M. M. (2005, outubro). Um estudo empírico sobre o Ebitda como representação do fluxo de caixa operacional: estudo em empresas brasileiras. In Anais do $5^{\circ}$ Congresso USP de Controladoria e Contabilidade, São Paulo, SP.

Sinnet, W. M. (2002, outubro). Why private companies stay private. Financial Executive International, 18(7), 51-53.

Souza, J. A. S., Costa, W. B., Almeida, J. E. F., \& Bortolon, P. M. (2013). Determinantes e consequências do fechamento de capital nas práticas de gerenciamento de resultados. Revista Evidenciação Contábil \& Finanças, 1(1), 38-57

Tripodi, T., Fellin, P., \& Meyer, H. J. (1981). Análise da pesquisa social: diretrizes para o uso de pesquisa em serviço social e ciências sociais (2a ed.). Rio de Janeiro: Francisco Alves.

Weir, C., Laing, D., \& Wright, M. (2005, setembro). Undervaluation, private information, agency costs and the decision to go private Applied Financial Economics, 15(13), 947-961.

World Federation of Exchanges. (2014). Statistics. Recuperado de http:// www.world-exchanges.org/statistics.

Zillmer, P. (2002). Public to private-transaktionen in Deutschland: eine empirische analyse öffentlicher Übernahmeangebote. Finanzbetr, 4 , 490-495.

Correspondence Address:

Patricia Maria Bortolon

Departamento de Ciências Contábeis, Universidade Federal do Espírito Santo

Avenida Fernando Ferrari, 514 - CEP: 29075-910

Goiabeiras - Vitória - ES

E-mail: patricia:bortolon@ufes.br 